\title{
Using stable isotopes to unravel and predict the origins of great cormorants (Phalacrocorax carbo sinensis) overwintering at Kinmen
}

\author{
Yuan-Mou Chang ${ }^{1 \dagger}$, Kent A. Hatch ${ }^{1 * \dagger \dagger}$, Tzung-Su Ding ${ }^{2 * \star, \dagger}$, Dennis L. Eggett ${ }^{3}$, \\ Hsiao-Wei Yuan ${ }^{2}$ and Beverly L. Roeder ${ }^{1}$ \\ ${ }^{1}$ Department of Biology, Brigham Young University, 401 WIDB, Provo, UT 84602-5181, USA \\ ${ }^{2}$ School of Forestry and Resource Conservation, National Taiwan University, No. 1, Sec. 4, Roosevelt Road, Taipei 106, Taiwan \\ ${ }^{3}$ Department of Statistics, Brigham Young University, 230 TMCB, Provo, UT 84602-5181, USA
}

Received 16 July 2007; Revised 1 February 2008; Accepted 4 February 2008

\begin{abstract}
The Food and Agricultural Organization of the United Nations and the World Organization for Animal Health have called for a better understanding of the role that migrating birds may play in spreading H5N1 highly pathogenic avian influenza (HPAI). Bird banding, traditionally used in studies of migration, is limited by low recapture rates. Telemetry can only be applied to larger species and a limited number of birds. We show that analyses of multiple stable isotopes $\left(\delta^{13} \mathrm{C}, \delta^{15} \mathrm{~N}, \delta^{18} \mathrm{O}\right.$ and $\delta \mathrm{D})$ can provide an understanding of the number of breeding populations represented at large congregations of wintering birds, probable locations of these breeding populations, and which breeding populations do not contribute migrants to a wintering site. As Asia is thought to be the origin of many HPAI strains and the center of their evolution, and as bird migration is poorly understood in this part of the world, we recommend that, in addition to banding, satellite, and VHF telemetry, the stable isotope analysis of migration patterns should become a part of long-term surveillance studies. Copyright (C) 2008 John Wiley \& Sons, Ltd.
\end{abstract}

The risk to human health of the H5N1 highly pathogenic avian influenza (HPAI) is widely acknowledged, and efforts are underway to prepare for a possible pandemic. ${ }^{1}$ Discoveries of the survival of infected birds, ${ }^{2-5}$ as well as outbreaks of HPAI among migratory wild birds in 2005 and $2006,{ }^{6,7}$ have led the Food and Agricultural Organization of the United Nations and the World Organization for Animal Health to call for a better understanding of the role that migrating birds may play in spreading HPAI. ${ }^{8}$ In particular, they call for a more precise understanding of flyways and congregation sites where large numbers of birds may mix and spread HPAI.

Naturally occurring stable isotopes found in feathers can be an important investigative tool to examine potential links between the breeding and wintering grounds of migratory birds. ${ }^{9}$ Proteins formed during the growth of the feather become metabolically inert. They then form a permanent record in which stable isotopes of hydrogen and oxygen reflect the local environmental conditions in which

*Correspondence to: K. A. Hatch, Department of Biology, Brigham Young University, 401 WIDB, Provo, UT 84602-5181, USA. E-mail: khatch@byu.edu

**Correspondence to: T.-S. Ding, School of Forestry and Resource Conservation, National Taiwan University, No. 1, Sec. 4, Roosevelt Road, Taipei 106, Taiwan.

E-mail: ding@ntu.edu.tw

${ }^{\dagger}$ These authors contributed equally to this work.

Contract/grant sponsor: Kinmen National Park of Taiwan. the feather was grown, while stable isotopes of carbon and nitrogen are influenced by the local diet. Therefore, the origin of a bird can often be inferred from knowledge of the isotopic values of feathers compared with the isotopic signatures of the local environment and diet. ${ }^{9,10}$

We chose to study the migration of Phalacrocorax carbo sinensis (the great cormorant) because of its potential to bring HPAI to Taiwan. Although HPAI has not yet been detected in Taiwan, ${ }^{11}$ individuals of P. c. sinensis infected with HPAI have been found elsewhere. ${ }^{12,13}$ Kinmen Island, which lies about $5 \mathrm{~km}$ off the coast of China $\left(24^{\circ} 44^{\prime} \mathrm{N}, 183^{\circ} 33^{\prime} \mathrm{E}, 150 \mathrm{~km}^{2}\right.$, Fig. 1) and is administered by Taiwan, is the location of one of the two largest congregations of wintering $P . c$. sinensis in East Asia. These wintering P. c. sinensis are also a focal attraction for ecotourism to Kinmen. The large number of cormorants wintering at Kinmen (greater than 10000 individuals), and the likelihood that they come from many different breeding populations, suggest the possibility that they could be a vector for bringing HPAI to Kinmen.

Although $\delta \mathrm{D}$ values of feathers have typically been compared with the $\delta \mathrm{D}$ of precipitation to infer migration, ${ }^{14,15}$ the distributions of $\delta \mathrm{D}$ and $\delta^{18} \mathrm{O}$ in precipitation across Asia are not as precisely known as in North America and Europe. This is because there are fewer data collection sites and the frequency of data collection is more sporadic in Asia. ${ }^{16}$ This makes it more difficult to infer the origins of birds by comparing the $\delta \mathrm{D}$ values of precipitation and of feathers in Asia alone. Consequently, we sought to infer breeding 


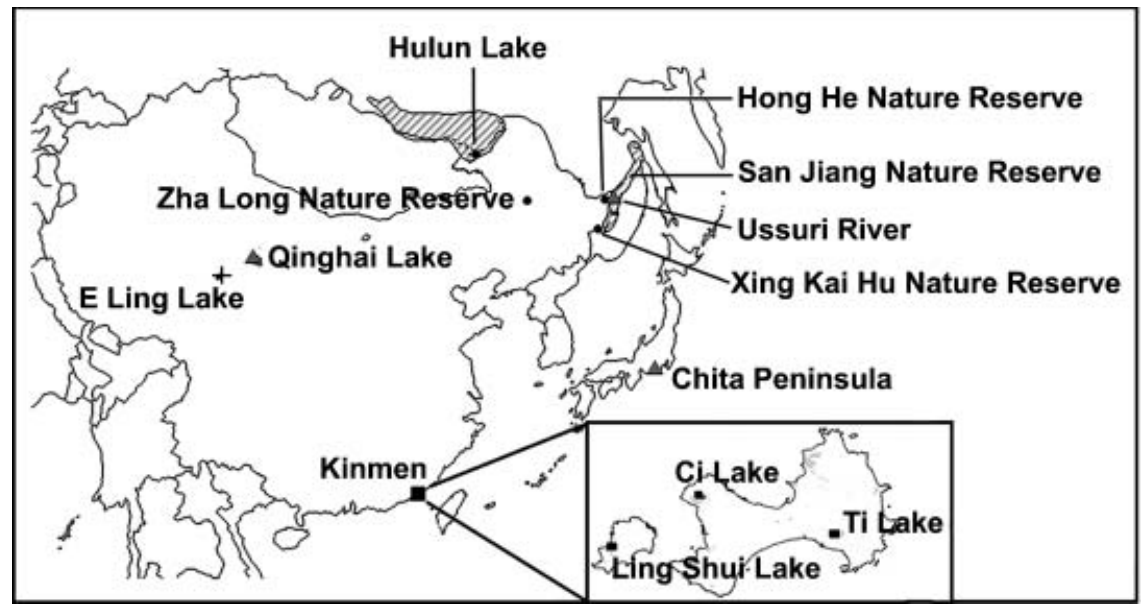

Figure 1. East Asia breeding range and Kinmen wintering sites of Phalacrocorax carbo sinensis. The locations marked by black circles indicate where cormorants formerly bred but where none were found during our July 2005 visit. The site with breeding cormorants that we did not visit is marked by a plus sign. The sites with breeding individuals and where feathers were collected are marked with grey triangles. These three sites are Qinghai Lake, Ussuri River and Chita Peninsula. Ci Lake, Ti Lake and Ling Shui Lake are the roosting sites at Kinmen in winter and are indicated by black squares.

locations of $P$. c. sinensis wintering at Kinmen based on the direct comparison of $\delta^{13} \mathrm{C}, \delta^{15} \mathrm{~N}, \delta^{18} \mathrm{O}$ and $\delta \mathrm{D}$ values of feathers collected at both wintering and breeding sites.

\section{EXPERIMENTAL}

\section{Feather collection}

An extensive literature review revealed at least 19 sites where P. c. sinensis have been known to breed in East Asia (Table 1,
Fig. 1). While P. c. sinensis breeding sites are also likely to occur in Siberia (Dr Sergey Surmach, personal communication), we did not visit these sites because little information has been published on them and because of the difficulty of obtaining visas to travel to these sites. However, we visited 10 of the 19 sites above (Fig. 1) in July 2006 and found breeding P. c. sinensis at four sites only: Qinghai Lake (a saline lake), E Ling Lake, Ussuri River in China, and Chita Peninsula in Japan. ${ }^{17}$ This suggests a significant loss of P. c. sinensis breeding sites. We

Table 1. Possible breeding sites of great cormorants (Phalacrocorax carbo sinensis) in East Asia

\begin{tabular}{|c|c|c|c|}
\hline Place name & Position & Habitat type & Sources \\
\hline Tang Wang River & Tang Yuan Co., Hei Long Jiang Province & Swamp & 1 \\
\hline Yalu River & Fu Yuan Co., Hei Long Jiang Province & Swamp & 1 \\
\hline San Jiang Nature Reserve* & Fu Yuan Co., Hei Long Jiang Province & Swamp & 1 \\
\hline Hong He Nature Reserve ${ }^{*}$ & Fu Yuan Co., Hei Long Jiang Province & Swamp & 1 \\
\hline $\begin{array}{l}\text { Qi Hu Lin River and A Bu } \\
\text { Xin River Swamp }\end{array}$ & $\begin{array}{l}\text { Hu Lin Co. and Rao He Co., } \\
\text { Hei Long Jiang Province }\end{array}$ & Swamp & 1 \\
\hline Xing Kai Hu Nature Reserve ${ }^{*}$ & Mi Shan City, Hei Long Jiang Province & Lake and swamp & 1 \\
\hline Zha Long Nature Reserve & Qiqihar City, Hei Long Jiang Province & Swamp & 1,2 \\
\hline Ussuri River $^{* \dagger}$ & $\begin{array}{l}\text { The boundary river of Northeast China } \\
\text { and south of the Russian Far East, Hei Long Jiang Province }\end{array}$ & River & 1 \\
\hline Hulun Lake & Hulun Buir Grassland, Inner Mongolia Autonomous Region & Swamp & 1 \\
\hline Wu Liang Su Hai & Ba Yan Zhao Er City, Inner Mongolia Autonomous Region & Lake & 1 \\
\hline Ha Su Hai & Hu He Hao Te City, Inner Mongolia Autonomous Region & Lake and swamp & 1 \\
\hline $\mathrm{Hu} \mathrm{Tu} \mathrm{Bi}$ & Dzungaria, Xinjiang Uyghur Autonomous Region & Reservoir & 3 \\
\hline Zha Ling Lake*, E Ling Lake ${ }^{*}$ & Ma Duo Co and Qu Ma Lai Co., Qinghai Province & Swamp & 1 \\
\hline $\mathrm{Ri} \mathrm{Tu}, \mathrm{Ge}$ Er & South Part of Tibet Autonomous Region & - & 1 \\
\hline Chita Peninsula $^{* \dagger}$ & Japan & Lake & 4 \\
\hline
\end{tabular}

*Indicates breeding sites visited in July 2005.

†Indicates breeding birds found.

1: China Swamps/Wetlands Database.

2: Liu JS, et al. Wild Animal 1994; 5: 19.

3: Fan XS, University Bulletin of Shihezi University 1999; 3: 1.

4: Johnsgard PA. Cormorants, Darters, and Pelicans of the World, Smithsonian Institution Press: Washington and London, 1993. 
were unable to collect feathers from E Ling Lake in China because of the difficulty accessing the site. We also collected feathers once a month from $P$. c. sinensis wintering at Kinmen from December 2005 to February 2006.

Rather than capturing and removing feathers from live adult birds, we chose to collect newly dropped feathers found lying on the ground ${ }^{18}$ including primary, secondary and tail feathers at breeding sites and at Kinmen. We are confident that all the collected feathers were newly dropped because these feathers were neither weathered, nor damaged, nor covered by a layer of dirt or dust. We ensured that the collected feathers were from different individuals by collecting them under widely separated nests at breeding sites and under separated roosting trees (Casuarina equisetifolia) at Kinmen. We also collected body feathers or flight feathers from dead nestlings which had fallen out of their nests at the breeding sites. Since the nestlings had not yet migrated, the isotopic signatures of their feathers must reflect that of the local habitats. ${ }^{19,20}$ We collected feathers from a total of 19, 21 and 48 birds from breeding sites at Qinghai Lake, Ussuri River and
Chita Peninsula, respectively, for stable isotope analysis. At Kinmen we also collected a total of 39, 27 and 32 feathers from Ci Lake, Tai Lake and Ling Shui Lake, respectively.

\section{Feather cleaning and sample preparation}

Before cleaning, we removed the vane of each feather and excluded $2 \mathrm{~cm}$ of the base (proximal) portion of the rachis including the calamus because this part is close to the subdermal portion and has been shown to differ isotopically from the rest of the feather. ${ }^{21}$ We then sonicated the feathers in distilled water for $30 \mathrm{~min}$, followed by sonication in petroleum ether for an additional $30 \mathrm{~min}$ to remove contaminants from the surface of the feathers. They were then air-dried in a fume hood.

Once cleaned, we cut the samples from both the tip and the base of each feather. Each sample was placed in a separate tin capsule for $\delta^{13} \mathrm{C}$ and $\delta^{15} \mathrm{~N}$ analysis and in a pre-combusted silver capsule for $\delta^{18} \mathrm{O}$ and $\delta \mathrm{D}$ analysis and then weighed. The sample weights ranged from 0.7 to $0.8 \mathrm{mg}$ for $\delta^{13} \mathrm{C}$ and $\delta^{15} \mathrm{~N}$ analysis and from 0.135 to $0.165 \mathrm{mg}$ for $\delta^{18} \mathrm{O}$ and $\delta \mathrm{D}$ analysis. All samples and

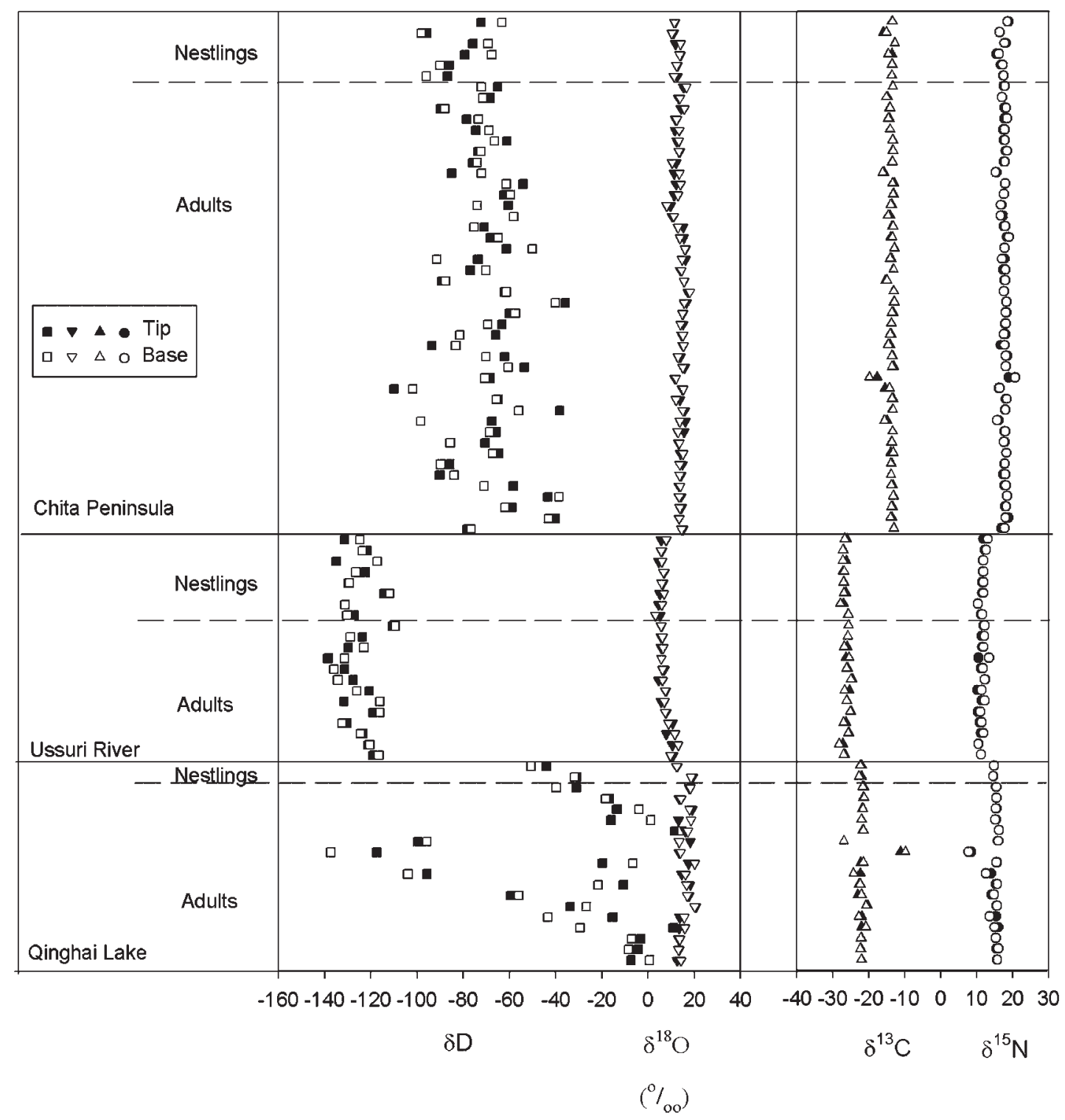

Figure 2. $\delta^{13} \mathrm{C}, \delta \mathrm{D}, \delta^{15} \mathrm{~N}$ and $\delta^{18} \mathrm{O}$ values of the tip and base of the Phalacrocorax carbo sinensis feathers from breeding sites. 
the standards for $\delta^{18} \mathrm{O}$ and $\delta \mathrm{D}$ analysis were stored in plastic culture trays, loosely covered with the lid, and were allowed to equilibrate at room temperature with ambient moisture in the air for 5 days prior to analysis.

\section{Isotopic analysis}

The $\delta^{13} \mathrm{C}$ and $\delta^{15} \mathrm{~N}$ of the feathers were analyzed using an elemental analyzer (Costech ECS 4010, Valencia, CA, USA) coupled to a Delta V isotope-ratio mass spectrometer (Finnigan, Bremen, Germany). External standards used for carbon were UCLA Carrera (a working standard from Ian Kaplan's laboratory, UCLA $\delta^{13} \mathrm{C}=2.52 \%$ ) and LSVEC (NIST, $\delta^{13} \mathrm{C}=-46.48 \%$ ). For nitrogen, we used USGS 25 (NIST, $\delta^{15} \mathrm{~N}=-30.4 \%$ ) and USGS 26 (NIST, $\delta^{15} \mathrm{~N}=53.5 \%$ ) as external standards.

For $\delta^{18} \mathrm{O}$ and $\delta \mathrm{D}$ analysis, silver capsules containing feather samples were analyzed using a high-temperature conversion elemental analyzer (TC/EA, ThermoFinnigan, Bremen, Germany) connected to a Finnigan Delta V isotope-ratio mass spectrometer. We analyzed samples of the tips and bases of feathers of 6-12 birds from each site at the Stable
Isotope Research Facility (SIRFER) at the University of Utah using their in-house standards. We then ran the remaining feathers at Brigham Young University using the feathers that we had run at SIRFER as in-house standards.

All stable isotope values of the samples are expressed in 'delta' $(\delta)$ notation. Delta values for carbon and nitrogen are expressed relative to Pee Dee Belemnite (PDB) and atmospheric nitrogen, respectively. ${ }^{22,23}$ Delta values for hydrogen and oxygen are expressed relative to V-SMOW (Vienna Standard Mean Ocean Water). ${ }^{24}$ The overall precision of the isotope measurements was $\pm 0.05 \%$ for carbon and nitrogen, $\pm 0.1 \%$ for oxygen, and $\pm 1 \%$ for hydrogen.

\section{Data analysis}

We designed our statistical analyses to answer the following questions: (1) can we use stable isotopes to infer breeding sites, (2) are there isotopic differences between feathers from different breeding sites with regard to age and feather type, (3) could P. c. sinensis wintering at Kinmen have come from the breeding sites we sampled, and (4) if they did not migrate

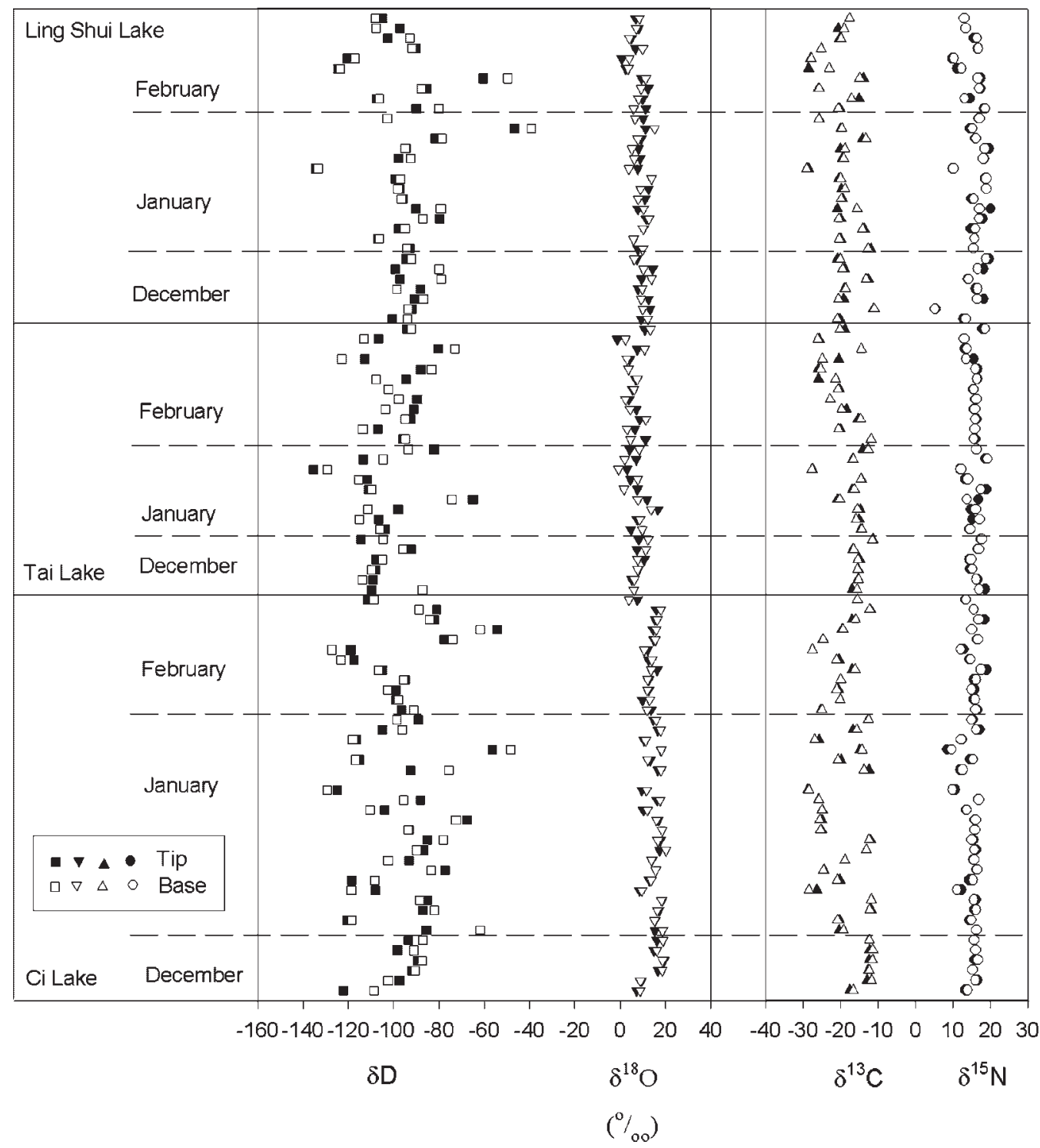

Figure 3. $\delta^{13} \mathrm{C}, \delta \mathrm{D}, \delta^{15} \mathrm{~N}$ and $\delta^{18} \mathrm{O}$ values of the tip and base of the Phalacrocorax carbo sinensis feathers from Ci Lake, Ti Lake and Ling Shui Lake roosting sites at Kinmen in winter. 
from these breeding sites, from which locations could they have possibly migrated? We first analyzed feathers that we collected to establish that their stable isotopes could be used to infer breeding sites. This was done by using a paired t-test of the tips and bases of the rachis of all the feathers. We found no significant difference in these two values of each feather (see below) and we, therefore, averaged the isotope values of tip and base of the rachis to represent the value of each feather for further comparison. We then used site (Qinghai Lake, Ussuri River and Chita Peninsula), age (adult and nesting) and feather type (body feather, primary feather, secondary feather and tail feather) as factors in a single full model analysis of variance (ANOVA) to compare feather delta values for each isotope from breeding sites and used a Tukey's post hoc test to determine differences within factors. We used a post hoc t-test to test the difference of the isotopic values between the feathers of the nestlings and adults within a breeding site. To determine whether it is possible that $P$. c. sinensis wintering at Kinmen could come from breeding sites at Qinghai Lake, Ussuri River, or the Chita Peninsula, we computed the multivariate normal distribution for $\delta^{13} \mathrm{C}, \delta \mathrm{D}, \delta^{15} \mathrm{~N}$ and $\delta^{18} \mathrm{O}$ for each breeding site and then computed a Hotelling's t-squared test for each site and observation. P. c. sinensis were assumed to come from the specific breeding site if $\mathrm{T}^{2}<9.49, \mathrm{X}^{2}{ }_{0.95,4}$; otherwise they were assumed to come from sites other than the three from which we collected feathers. Finally, to answer the question of where these $P$. c. sinensis breed and roughly how many breeding populations winter at Kinmen, we used cluster analysis to objectively group wintering $P$. c. sinensis based on the stable isotope values of their feathers. We used a hierarchical approached based on the mean distance. ${ }^{25}$ We tested this approach using the data we collected from birds at our three breeding sites.

\section{RESULTS}

\section{Isotopic signature of feathers from breeding sites}

Our data indicate that the feathers we collected were grown on the breeding grounds. First, we found no statistically significant differences in the isotopic values of base and tip of the rachis from the same feathers for $\delta^{13} \mathrm{C}, \delta \mathrm{D}, \delta^{15} \mathrm{~N}$ or $\delta^{18} \mathrm{O}$ values (Table 2, Figs. 2 and 3 ). This indicates that the entire feather was grown at a single location. Second, $\delta^{13} \mathrm{C}, \delta \mathrm{D}, \delta^{15} \mathrm{~N}$ and $\delta^{18} \mathrm{O}$ values were significantly different between breeding sites (Tables 3 and 4). Third, there were no significant differences in $\delta^{13} \mathrm{C}, \delta \mathrm{D}, \delta^{15} \mathrm{~N}$ and $\delta^{18} \mathrm{O}$ between different feather types (Table 3 and Fig. 4). Finally, the feathers from nestlings were not significantly different from

Table 2. Paired t-tests of isotopic values of base and tip from the same feathers $(n=186)$. Means \pm 1 SE is shown. The significant level is $P<0.05$

\begin{tabular}{lrrrr}
\hline Isotope value (\%) & Tip & Base & t-value (Df) & $P$ \\
\hline$\delta^{13} \mathrm{C}$ & $-18.68 \pm 0.38$ & $-18.71 \pm 0.39$ & $0.42(185)$ & 0.67 \\
$\delta \mathrm{D}$ & $-86.68 \pm 2.26$ & $-87.11 \pm 2.22$ & $0.66(185)$ & 0.51 \\
$\delta^{15} \mathrm{~N}$ & $11.50 \pm 0.32$ & $11.57 \pm 0.33$ & $-0.45(185)$ & 0.65 \\
$\delta^{18} \mathrm{O}$ & $15.46 \pm 0.19$ & $15.50 \pm 0.18$ & $-0.74(185)$ & 0.46 \\
\hline
\end{tabular}

Copyright (C) 2008 John Wiley \& Sons, Ltd.
Table 3. Effects of sites (Qinghai Lake, Ussuri River and Chita Peninsula), ages (adult and nestling) and feather types (body feather, primary feather, secondary feather and tail feather) on isotopic values of feathers $(n=88)$ collected at breeding sites

\begin{tabular}{lccrc}
\hline Effect & $\begin{array}{c}\text { Df for } \\
\text { numerator }\end{array}$ & $\begin{array}{c}\text { Df for } \\
\text { denominator }\end{array}$ & F & P \\
\hline$\delta^{13} \mathrm{C}$ & & & & \\
$\quad$ Place & 2 & 85 & 485.79 & $<0.0001$ \\
Age & 1 & 76 & 0.61 & 0.44 \\
$\quad$ Feather type & 3 & 76 & 1.02 & 0.39 \\
$\delta \mathrm{D}$ & & & & \\
Place & 2 & 85 & 102.43 & $<0.0001$ \\
Age & 1 & 76 & 0.47 & 0.49 \\
Feather type & 3 & 76 & 0.33 & 0.81 \\
$\delta^{15} \mathrm{~N}$ & & & & \\
Place & 2 & 85 & 256.88 & $<0.0001$ \\
Age & 1 & 76 & 0.02 & 0.88 \\
Feather type & 3 & 76 & 1.18 & 0.32 \\
$\delta^{18} \mathrm{O}$ & & & & \\
Place & 2 & 77 & 115.93 & $<0.0001$ \\
Age & 1 & 76 & 0.88 & 0.35 \\
Feather type & 3 & 77 & 2.02 & 0.66 \\
\hline
\end{tabular}

the dropped feathers of adults in $\delta^{13} \mathrm{C}, \delta \mathrm{D}, \delta^{15} \mathrm{~N}$ and $\delta^{18} \mathrm{O}$ values within a breeding site (Fig. 4 , Table 5). Since the feathers of nestlings must have grown at the breeding site, this strongly indicates that the adult feathers did also.

\section{Origin of $P$. c. sinensis wintering at Kinmen}

Our results show that it is very unlikely that $P$. c. sinensis wintering at Kinmen could come from breeding sites at Qinghai Lake, Ussuri River, or the Chita Peninsula. There is a possibility that three of the 98 P. c. sinensis sampled at Kinmen may have spent the breeding season at Qinghai Lake, two on the Ussuri River and two at the Chita Peninsula. However, it reasonably excludes the possibility that 91 of the P. c. sinensis summered at the above locations (Table 6).

Having determined that most $P$. c. sinensis wintering at Kinmen do not breed on either Qinghai Lake, the Chita Peninsula, or at the Ussuri River, we next questioned where these P. c. sinensis breed and roughly how many breeding populations winter at Kinmen. When we tested cluster analysis on our known data, it reproduced the breeding populations quite closely (Table 7 ). When we applied this analysis to the data collected from the P.c. sinensis wintering

Table 4. Tukey's between site comparisons of the isotopic values $(\%)$ of feathers from breeding sites. Least-square means $\pm 1 \mathrm{SE}$ is shown

\begin{tabular}{lccc}
\hline & \multicolumn{3}{c}{ Breeding sites } \\
\cline { 2 - 4 } $\begin{array}{l}\text { Isotope } \\
\text { value (\%) }\end{array}$ & $\begin{array}{c}\text { Qinghai } \\
\text { Lake }(\mathrm{n}=19)\end{array}$ & $\begin{array}{c}\text { Ussuri } \\
\text { River }(\mathrm{n}=21)\end{array}$ & $\begin{array}{c}\text { Chita Peninsula } \\
(\mathrm{n}=48)\end{array}$ \\
\hline$\delta^{13} \mathrm{C}$ & $-21.65 \pm 0.37^{\mathrm{a}}$ & $-26.34 \pm 0.35^{\mathrm{b}}$ & $-13.90 \pm 0.23^{\mathrm{c}}$ \\
$\delta \mathrm{D}$ & $-33.20 \pm 4.71^{\mathrm{a}}$ & $-124.96 \pm 4.48^{\mathrm{b}}$ & $-70.66 \pm 2.97^{\mathrm{c}}$ \\
$\delta^{15} \mathrm{~N}$ & $14.90 \pm 0.24^{\mathrm{a}}$ & $11.57 \pm 0.23^{\mathrm{b}}$ & $17.71 \pm 0.15^{\mathrm{c}}$ \\
$\delta^{18} \mathrm{O}$ & $16.34 \pm 0.53^{\mathrm{a}}$ & $6.96 \pm 0.45^{\mathrm{b}}$ & $13.51 \pm 0.41^{\mathrm{c}}$ \\
\hline
\end{tabular}

Different letter superscripts within a row indicate significantly different values $(P<0.05)$. 

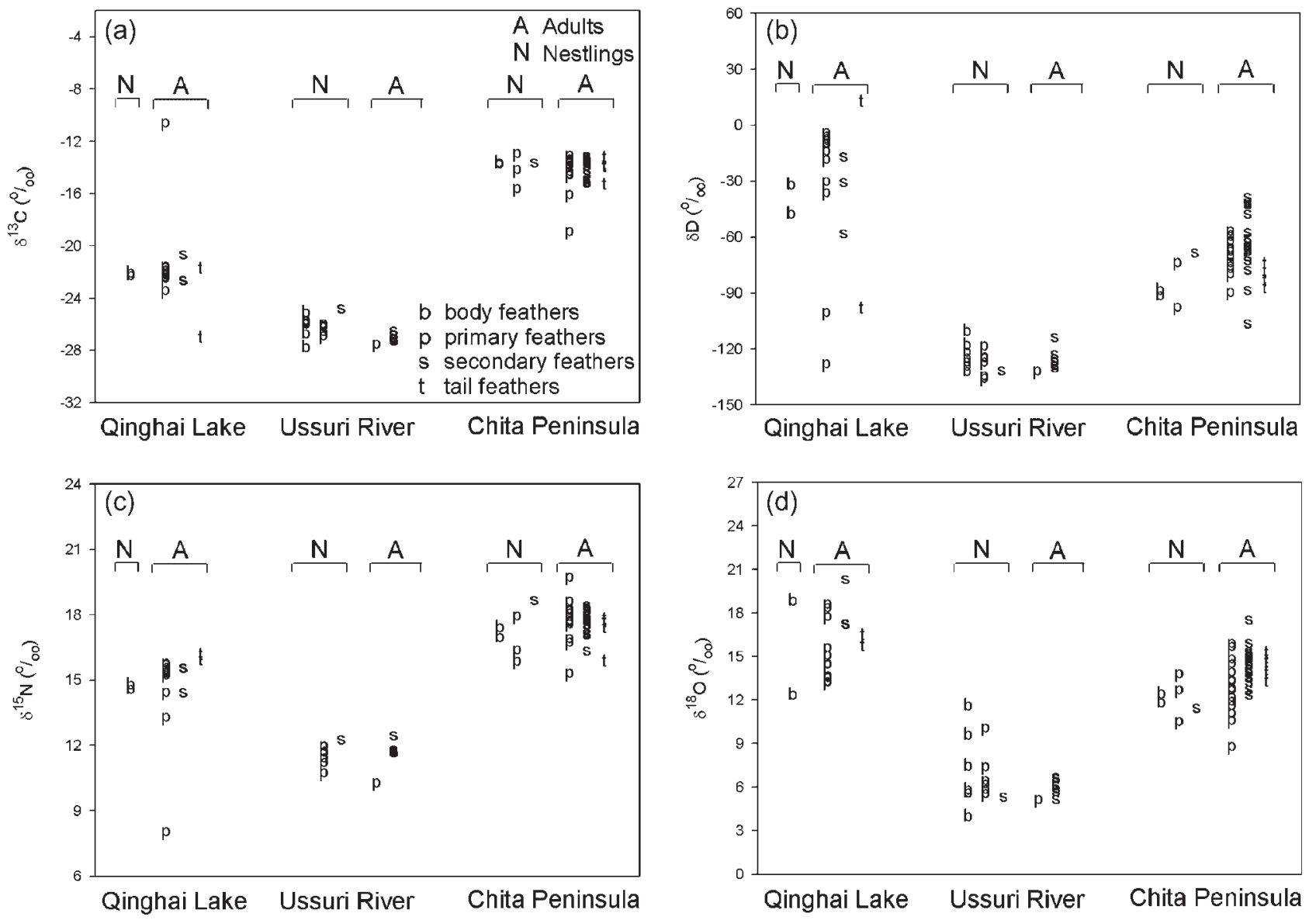

Figure 4. $\delta^{13} \mathrm{C}, \delta \mathrm{D}, \delta^{15} \mathrm{~N}$ and $\delta^{18} \mathrm{O}$ values of Phalacrocorax carbo sinensis feathers from nestlings and adults of breeding sites. The statistical results are shown in Tables 2,3,4 and 5 .

Table 5. Post hoc t-test between the isotopic values (\%) between the feathers of the nestlings and adults within a breeding site. The level of significance is $P<0.05$

\begin{tabular}{lccc}
\hline & \multicolumn{3}{c}{$P$ values between nestlings and adults } \\
\cline { 2 - 4 } Isotopes & Qinghai Lake & Ussuri River & Chita Peninsula \\
\hline$\delta^{13} \mathrm{C}$ & 0.68 & 0.24 & 0.96 \\
$\delta \mathrm{D}$ & 0.66 & 0.99 & 0.17 \\
$\delta^{15} \mathrm{~N}$ & 0.81 & 0.54 & 0.26 \\
$\delta^{18} \mathrm{O}$ & 0.62 & 0.07 & 0.06 \\
\hline
\end{tabular}

Table 6. Number of P. c. sinensis wintering at Kinmen (three different locations) which might reasonably be inferred to have spent the summer at either Qinghai Lake, the Ussuri River, or Japan's Chita Peninsula based on Hotelling's t-squared test

\begin{tabular}{lccccc}
\hline & \multicolumn{4}{c}{ Breeding sites } & \\
\cline { 2 - 5 } Kinmen & $\begin{array}{c}\text { Qinghai } \\
\text { Lake }\end{array}$ & $\begin{array}{c}\text { Ussuri } \\
\text { River }\end{array}$ & $\begin{array}{c}\text { Chita } \\
\text { Peninsula }\end{array}$ & $\begin{array}{c}\text { Other } \\
\text { sites }\end{array}$ & Total \\
\hline Ling Shui Lake & 2 & 1 & 1 & 28 & 32 \\
Tai Lake & 0 & 0 & 1 & 26 & 27 \\
Ci Lake & 1 & 1 & 0 & 37 & 39 \\
Total & 3 & 2 & 2 & 91 & 98 \\
\hline
\end{tabular}

Copyright (C) 2008 John Wiley \& Sons, Ltd. at Kinmen, the analysis produced nine clusters plus two outliers. Assuming these represent distinct breeding populations, we suggest that approximately $65 \%$ of the $P$. c. sinensis wintering at Kinmen come from four of 9-11 breeding populations (Table 8 , bold italics), while $25 \%$ come from the remaining five breeding populations. The two outliers may represent additional populations. Our data also suggest that approximately $70 \%$ of the wintering P.c. sinensis at Ling Shiu Lake were from breeding populations three and four, and that approximately $60 \%$ of the P.c. sinensis at Tai Lake were from breeding population three. Likewise, about

Table 7. Analysis of feathers collected at three breeding sites. Cluster analysis correctly assigned $97 \%$ of breeding cormorants to the correct breeding site based on stable isotope analysis of feathers

$$
\text { Breeding sites }
$$

Cluster name Qinghai Lake Ussuri River Chita Peninsula Total

\begin{tabular}{lrrrr}
\hline 1 & 0 & 0 & 48 & 48 \\
2 & 16 & 0 & 0 & 16 \\
3 & 0 & 21 & 0 & 21 \\
4 & 2 & 0 & 0 & 2 \\
5 & 1 & 0 & 0 & 1 \\
Total & 19 & 21 & 48 & 88 \\
\hline
\end{tabular}


Table 8. Cluster analysis of feathers collected at three wintering sites in Kinmen. The clusters in the table represent inferred breeding populations to which wintering $P$. c. sinensis were assigned

\begin{tabular}{lllll}
\hline & \multicolumn{4}{c}{ Wintering sites } \\
\cline { 2 - 5 } Cluster name & Ling Shui Lake & Tai Lake & Ci Lake & Total \\
\hline $\mathbf{1}$ & 0 & 1 & $\mathbf{1 4}$ & 15 \\
$\mathbf{2}$ & 3 & 0 & $\mathbf{1 0}$ & 13 \\
$\mathbf{3}$ & $\mathbf{1 4}$ & 3 & 1 & 18 \\
$\mathbf{4}$ & $\mathbf{9}$ & $\mathbf{1 6}$ & 2 & 27 \\
5 & 0 & 0 & 6 & 6 \\
6 & 0 & 0 & 4 & 4 \\
7 & 3 & 3 & 0 & 6 \\
8 & 2 & 1 & 1 & 4 \\
9 & 0 & 3 & 0 & 3 \\
10 & 1 & 0 & 0 & 1 \\
11 & 0 & 0 & 1 & 1 \\
Total & 32 & 27 & 39 & 98 \\
\hline
\end{tabular}

Note: Cluster analysis clearly separated cormorants into 11 possible breeding populations: four major populations (bold italics), five minor populations, and two questionable populations based on one bird each. The major breeding origins of cormorants of each wintering site at Kinmen are indicated in bold. The numbers of feathers of each cluster do not imply the exact numbers of individuals coming from the breeding populations.
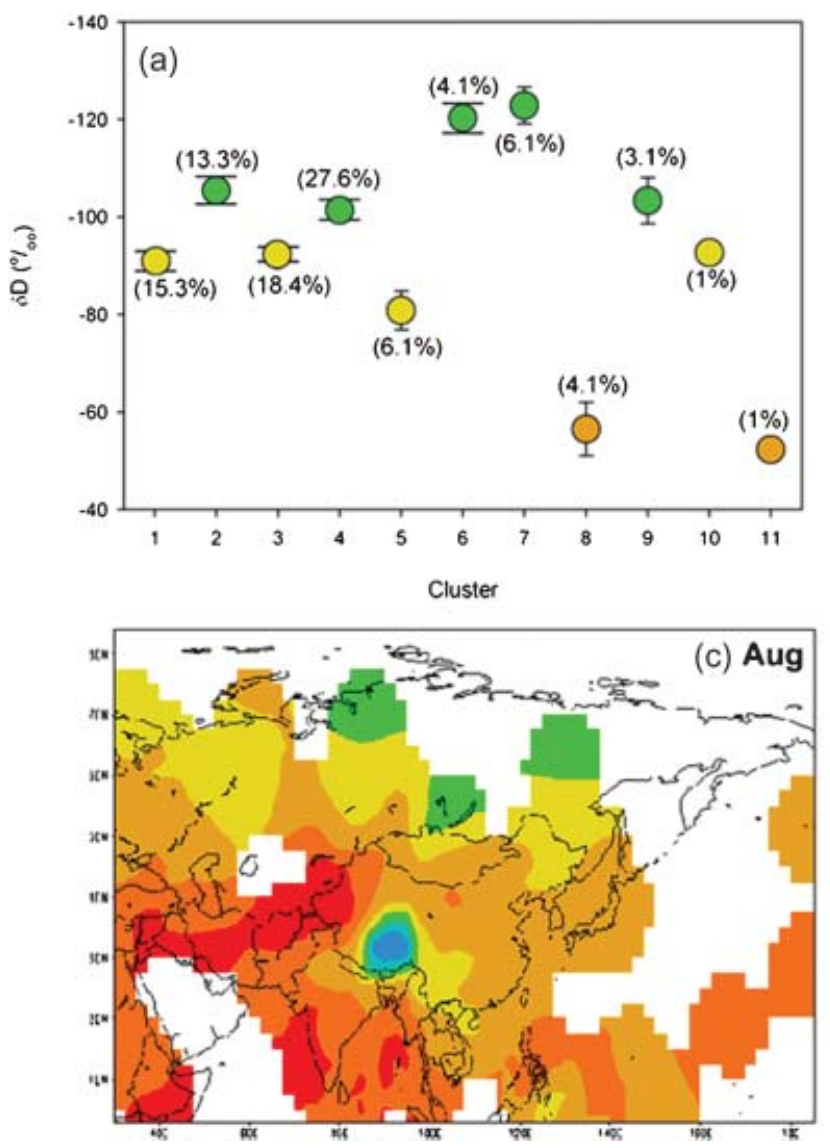

$60 \%$ of the P. c. sinensis at Ci Lake were from breeding populations one and two (Table 8).

Using $\delta^{13} \mathrm{C}, \delta \mathrm{D}, \delta^{15} \mathrm{~N}$ or $\delta^{18} \mathrm{O}$ values, we were able to largely exclude the possibility that cormorants wintering at Kinmen came from breeding populations at Qinghai Lake, Ussuri River or the Chita Peninsula. Cluster analyses using these isotopes also allowed us to infer the number of probable breeding populations present at Kinmen. However, because we did not collect feathers from breeding populations in Russia, we determined general locations of possible breeding sites of our hypothesized populations based on the comparisons of feather $\delta \mathrm{D}$ values with the mean $\delta \mathrm{D}$ of precipitation during the breeding season according to the best available $\delta \mathrm{D}$ isocline maps of Asia. ${ }^{16,26}$ The precipitation collecting sites used to create these maps are not continuously active, and the map is derived from spatially and temporally discontinuous data. We assumed no diet-tissue fractionation $^{27,28}$ and that the $\delta \mathrm{D}$ values of the precipitation are directly reflected in the feathers. This comparison suggests that approximately $50 \%$ of the P. C. sinensis wintering at Kinmen come from five breeding populations that may be located in the region around Lake Baikal or an area encompassing the Amur, Khabarovsk and Primorsky regions of Russia (Fig. 5, clusters 2, 4, 6, 7, and 9). It also
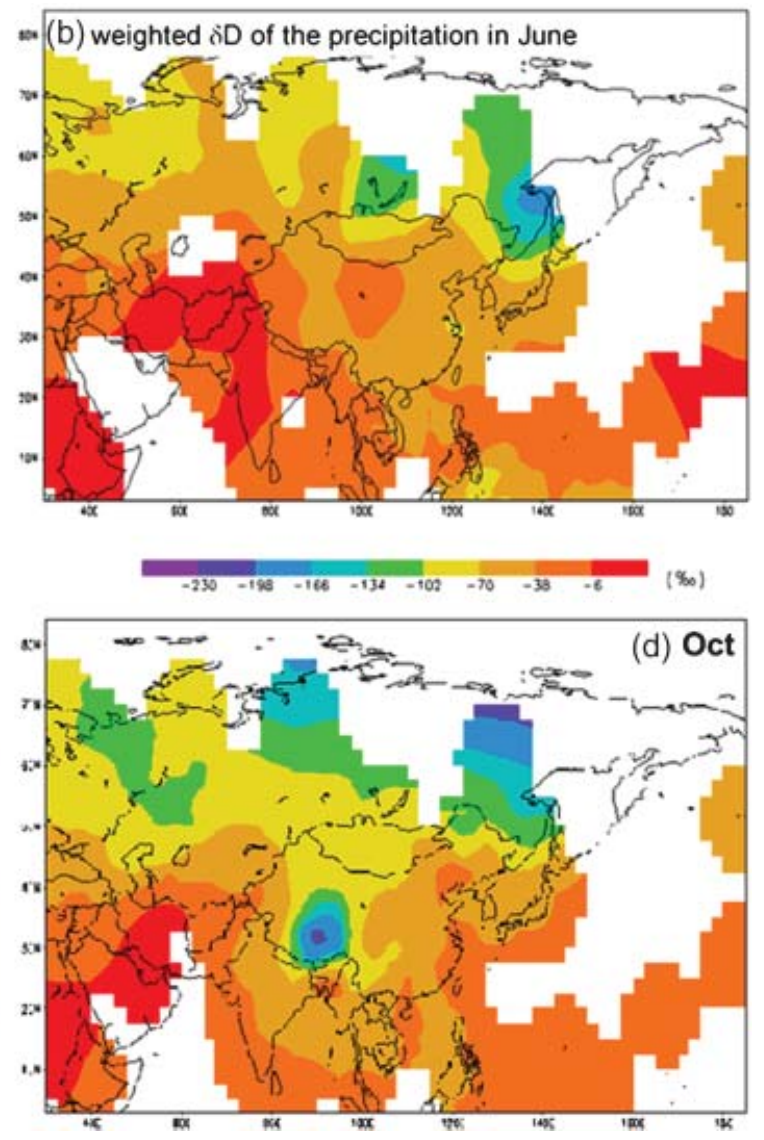

Figure 5. Inferred breeding region for each cluster of Phalacrocorax carbo sinensis feathers at Kinmen. The color of each cluster in (a) matches the color of the inferred breeding area in (b). Areas of the same colors in (b) have the same $\delta D$ values for mean June precipitation (adapted from Ref. ${ }^{71}$ ). We chose precipitation $\delta \mathrm{D}$ map in June as the example of our inference; due to the patterns of precipitation $\delta \mathrm{D}$ are similar among the months of molting periods, and consequently does not affect our inference (compare (b) with (c) and (d)). The percentage of feathers of each cluster is indicated in parentheses. The totals are given in Table 6. The percentages of feathers of each cluster do not imply the exact percentage of individuals coming from the breeding populations. 
suggests that approximately $40 \%$ may originate from four breeding populations that are probably found in Mongolia, the region just south of the Ussuri River, and possibly parts of Siberia (Fig. 5, clusters 1, 3, 5, and 10). Finally, approximately $5 \%$ of the P. c. sinensis may come from populations further south, possibly representing two distinct breeding populations (Fig. 5, clusters 8 and 11). The $\delta$ D values of the feathers from these individuals suggest the possibility that these P. . . sinensis may have come from breeding populations in China, Korea, or Japan, although these breeding sites could also be located in Mongolia or Siberia.

When the results of both the Hotelling's t-squared test and the cluster analysis are compared, the evidence suggests that it is unlikely that 96 of the 98 P. c. sinensis sampled at Kinmen summered at either Qinghai Lake, the Ussuri River, or the Chita Peninsula. It is possible that one of the remaining two may have migrated to Kinmen from the Ussuri River while the second may have come from the Chita Peninsula.

\section{DISCUSSION}

\section{Molting pattern}

Although the molting patterns of P. c. sinensis in East Asia have not been studied, many cormorants molt their flight feathers gradually during the months of late summer and autumn. ${ }^{29}$ However, some cormorants show a relatively complex and extended molt, meaning that some cormorants not only molt at their breeding sites in summer, but also extend their molt to non-breeding sites in winter. ${ }^{30,31}$

Our data suggest that most P.c. sinensis in East Asia molt flight and tail feathers before they migrate, i.e. over a 3-4 month period while they are still on their breeding grounds. First, we found no differences between the isotopic values of base and tip of the same feather rachis, indicating that the entire feather was grown at a single location. Second, since the feathers of nestlings must have grown at the breeding site and the feather isotopic values of adults are not different from those of nestlings within the same site, it is highly probable that the adult feathers have also grown at the breeding site. Third, we found that feather isotope values are primarily consistent within breeding sites. Studies on cormorants (Phalacrocorax carbo) ${ }^{18,30}$ and other migratory bird species ${ }^{26,32,33}$ show that within a species the feathers grown at the breeding areas have distinctly different isotope signatures from those at the wintering areas or intermediate locations. Therefore, if the P. c. sinensis in East Asia has an extended molt, ${ }^{30}$ we should find large variations in isotopic values within single feathers and/or between feathers from birds at the same breeding sites.

Moreover, even if we apply the published fractionation factor, ${ }^{15}$ it is very difficult to make the case that the $P$. c. sinensis grew these feathers at Kinmen. At Fuzhou, the place nearest to Kinmen with long-term records of the $\delta \mathrm{D}$ of the precipitation, the mean $\delta \mathrm{D}$ value of the precipitation from October to February is $-25 \%,{ }^{34}$ whereas the $\delta \mathrm{D}$ values of sea water usually range between -5 and $5 \%$, regardless of latitude. $^{35-37}$ Applying the $-25 \%$ fractionation factor measured between feather and water of red-wing black birds (Agelaius pheoniceus) ${ }^{15}$ to the $\delta \mathrm{D}$ value of sea water and wintertime precipitation at Kinmen suggests that feathers grown there should have a mean $\delta \mathrm{D}$ value between -20 and $-50 \%$. Instead, most feathers collected at Kinmen had $\delta \mathrm{D}$ values ranging primarily from -70 to $-120 \%$. This strongly suggests that these feathers were grown much further north, probably on the breeding grounds.

Our field observations also indicate that $P$. c. sinensis molt their flight and tail feathers before they migrate to Kinmen. We surveyed their roosting sites monthly and searched for feathers intensively at Kinmen. At a main roosting site (Ci Lake), several thousands of P. c. sinensis stayed 12-18 h daily from November to March. However, over the whole roosting site we were only able to collect a few dozen primary, secondary and tail feathers each month. In addition, none of the $P$. c. sinensis we collected (alive or dead) at Kinmen had any developing feathers. These observations, along with feather isotopic comparisons, provide strong evidence that most P. c. sinensis drop and regrow their flight feathers and tail feathers at breeding sites.

\section{Isotopic differences between feather isotopes of breeding populations}

Our study shows that stable isotopes can be used to differentiate the breeding populations of $P$. c. sinensis in East Asia. For nitrogen, feathers from Chita Peninsula had the highest $\delta^{15} \mathrm{~N}$ values, followed by feathers from Qinghai Lake and Ussuri River. However, it is hard to interpret what the differences in $\delta^{15} \mathrm{~N}$ values mean, since they can be caused by differences in the isotopic signature of the diets, ${ }^{24,38,39}$ trophic levels, ${ }^{40,41}$ and also by fasting or nutritional stress. $^{42,43}$

However, we can interpret the meaning of differences in $\delta^{13} \mathrm{C}$ values. ${ }^{9,41,44-46}$ It is generally accepted that animals with an entirely marine diet have higher $\delta^{13} \mathrm{C}$ values $(-12 \% 0 \sim-19 \%)$ than animals with a terrestrial or freshwater diet $\left(-20 \%\right.$ -27\%o). ${ }^{18,30,38,44,46-54}$ The $\delta^{13} \mathrm{C}$ values of feathers (range: -12.8 to $-18.8 \%$; Figs. 2 and 4 ) from Chita Peninsula suggest a strong marine dietary influence. This is also supported by our field observations which show that this population, although nesting around freshwater ponds, feeds mainly in Mikawa Bay and Ise Bay during the breeding seasons (Tzung-Su Ding, personal observation).

The $\delta^{13} \mathrm{C}$ values suggest that Qinghai Lake cormorants are mostly freshwater feeders while the comparatively negative $\delta^{13} \mathrm{C}$ values of Ussuri River cormorants strongly suggest that they are exclusively freshwater feeders (Figs. 2 and 4). Qinghai Lake cormorants were reported to mainly feed on Przewalski's naked carps (Gymnocypris przewalskii), an endemic species of Qinghai Lake. ${ }^{55,56}$ The Przewalski's naked carp is considered a 'salmonid analogue', with adults making annual spring migrations from Qinghai Lake into freshwater rivers to spawn. The adults then return to the lake in the summer. ${ }^{57,58}$ Although $\delta^{13} \mathrm{C}$ values of Przewalski's naked carps have not been reported, $\delta^{13} \mathrm{C}$ values of the Pacific salmon Oncorhynchus spp. ${ }^{30,59,60}$ tend to be more negative than those of marine fish, ${ }^{18,30,47,52}$ and more positive than those of freshwater fish. ${ }^{18,47,51,54,59,61,62}$ This provides a possible explanation for the pattern of $\delta^{13} \mathrm{C}$ values for the Qinghai Lake population. It is also worth noting that one feather collected at Qinghai Lake had a high $\delta^{13} \mathrm{C}$ value (10.51\%, Figs. 2 and 4). This suggests that this cormorant and 
possibly other individuals may prefer to feed on prey species found in Qinghai Lake.

The $\delta \mathrm{D}$ and $\delta^{18} \mathrm{O}$ values of feathers from Qinghai Lake were the highest, followed by those from Chita Peninsula and Ussuri River. It is reasonable that the feathers collected from Ussuri River have lower $\delta \mathrm{D}$ and $\delta^{18} \mathrm{O}$ values than those from Chita Peninsula and Qinghai Lake since the spatial distribution of $\delta \mathrm{D}$ and $\delta^{18} \mathrm{O}$ in the precipitation generally decreases with increasing latitude and increasing distances from the ocean in Asia. ${ }^{34}$ An interesting isotopic pattern occurs in Asia in which the $\delta \mathrm{D}$ values and $\delta^{18} \mathrm{O}$ values in the precipitation at Qinghai Lake and surrounding areas are much higher than that of precipitation in the coastal regions of China and Japan in summer. ${ }^{34}$ This may be due to the contribution to precipitation of evaporated groundwater that diffuses through the soil or is transpired by plants in this semi-arid region. ${ }^{63}$ Therefore, a high $\delta \mathrm{D}$ and $\delta^{18} \mathrm{O}$ in the precipitation may cause the high feather $\delta \mathrm{D}$ values and $\delta^{18} \mathrm{O}$ values of Qinghai Lake cormorants.

Although the variance in individual foraging behavior may cause differences in isotope patterns of individuals at the same site, ${ }^{9}$ the small variances in feather $\delta^{13} \mathrm{C}, \delta^{15} \mathrm{~N}$, and $\delta^{18} \mathrm{O}$ values within the same breeding population suggest that cormorants of the same breeding population feed on similar prey species. This corresponds with the observed feeding practices of $P$.c. sinensis, which are colonial birds and usually form a foraging flock with hundreds to thousands of individuals taking schooling fish. ${ }^{64}$ Thus they are probably feeding on similar prey.

\section{Origin of $P$. c. sinensis wintering at Kinmen}

Our analysis suggests that the P. c. sinensis gathered at Kinmen come from 9-11 different breeding populations over a large geographic range. However, the data suggest that most of these cormorants do not breed at Qinghai Lake, the Chita Peninsula, or Ussuri River. It also appears that cormorants roosting at Kinmen segregate according to breeding population.

Our inferences concur with observational data. P. C. sinensis banded at Qinghai Lake were recovered near the Bay of Bengal, India (Lai-Xing Lee, personal communication). P. c. sinensis at Chita Peninsula have long been considered a resident bird species, overwintering locally. ${ }^{17}$ Thus both our isotopic data and previous observational studies suggest that it is unlikely that Qinghai Lake and Chita Peninsula populations overwinter at Kinmen.

It is possible that Kinmen $P$. c. sinensis could come from North East China. Banded P. c. sinensis from Zha Long Nature Reserve, Hei Long Jiang Province, were recovered at Mingjiang Esturary, Fujian, in $1988{ }^{65}$ a place close to Kinmen. However, our visits suggest that Ussuri River is the only existing breeding site in North East China and few P.c. sinensis could come from this region. Our inference of origins based on $\delta \mathrm{D}$ alone suggests that $P$. c. sinensis wintering on Kinmen primarily come from further north than the Ussuri River. Dr Sergey Surmach's (personal communications) field observation shows that the breeding $P$. c. sinensis can currently be found at Lake Baikal and in an area encompassing the Amur, Khabarovsk and Primorsky regions. Our inferences of origins using $\delta \mathrm{D}$ alone seem not only to tally

Copyright (C) 2008 John Wiley \& Sons, Ltd. with Dr Surmach's observation, but also suggest some other potential breeding sites.

Although the utilization of $\delta \mathrm{D}$ in precipitation patterns to study the movements of migratory birds has become common, ${ }^{9,66}$ the degree of fractionation of $\delta \mathrm{D}$ between precipitation and feathers is still controversial. Previous studies have shown mixed results, with some showing enrichment of feathers, ${ }^{67-69}$ while others suggesting none. ${ }^{27,28}$ Since the diet of $P$. c. sinensis is aquatic, with very little or no terrestrial input, we assumed that there is little or no fractionation between the $\delta \mathrm{D}$ of precipitation and the $\delta \mathrm{D}$ of the feathers.

In addition, the accuracy and precision of such studies depend on the accuracy and precision of the $\delta \mathrm{D}$ values in precipitation maps. Since the continental patterns of $\delta \mathrm{D}$ in precipitation across Asia are not as precisely known as in North America and Europe, and the influences of food and drinking water on $\delta \mathrm{D}$ values of $P$. c. sinensis are not well understood, caution should be used when inferring breeding origins of P.c. sinensis wintering at Kinmen based on patterns of $\delta \mathrm{D}$ in precipitation alone.

\section{CONCLUSIONS}

Our study shows that the stable isotope approach has the potential to provide migratory information at the population level, to uncover the possible existence of previously unknown breeding populations, and to make coarse inferences and predictions concerning bird migration and possible future transmission of HPAI in East Asia. In contrast, satellite telemetry and VHF telemetry can only be applied to a limited number of individuals, but has a very high spatial and temporal resolution, which allows the precise assessment of bird movements. As Asia is thought to be the origin of many HPAI strains and the center of their evolution, and as migration is poorly understood in this part of the world, we therefore recommend that, in addition to banding, satellite and VHF telemetry, ${ }^{8}$ stable isotope analysis of migration patterns become a part of long-term surveillance studies. Moreover, combining multivariate analyses of stable isotopes with analyses of the phylogenic trees of birds and HPAI may provide an opportunity to better understanding the interaction of bird migrations and the spread of HPAI. ${ }^{10,70}$

\section{Acknowledgements}

We greatly appreciate S.-W. Fu for help with the field work, R. Bogardus and the students in K. A. Hatch's lab for feather cleaning and sample preparation, and S. Nelson and S. Sinervo for their comments and insights. We thank two anonymous reviewers for providing helpful comments on the manuscript. We are grateful to Dr Sergey Surmach (Institute of Biology and Soil Science, Russian Academy of Science) for providing the valuable field observation data for the breeding sites of Phalacrocorax carbo sinensis in Russia. Finally, we acknowledge financial and logistic support from Kinmen National Park of Taiwan. 


\section{REFERENCES}

1. Thomas JK, Noppenberger J. Am. J. Health-System Pharm. 2007; 64: 149.

2. Chen H, Smith GJD, Li KS, Wang J, Fan XH, Rayner JM, Vijaykrishna D, Zhang JX, Zhang LJ, Guo CT, Cheung CL, Xu KM, Duan L, Huang K, Qin K, Leung YHC, Wu WL, Lu HR, Chen Y, Xia NS, Naipospos TSP, Yuen KY, Hassan SS, Bahri S, Nguyen TD, Webster RG, Peiris JSM, Guan Y. Proc. Natl. Acad. Sci. USA 2006; 103: 2845.

3. Hulse-Post DJ, Sturm-Ramirez KM, Humberd I, Seiler P Govorkova EA, Krauss S, Scholtissek C, Puthavathana P, Buranathai C, Nguyen TD, Long HT, Naipospos TSP, Chen H, Ellis TM, Guan Y, Peiris JSM, Webster RG. Proc. Natl. Acad. Sci. USA 2005; 102: 10682.

4. Liu J, Xiao H, Lei F, Zhu Q, Qin K, Zhang XW, Zhang XL, Zhao D, Wang G, Feng Y, Ma J, Liu W, Wang J, Gao GF. Science 2005; 309: 1206.

5. Sturm-Ramirez KM, Ellis T, Bousfield B, Bissett L, Dyrting K, Rehg JE, Poon L, Guan Y, Peiris M, Webster RG. J. Virol. 2004; 78: 4892.

6. Gilbert M, Xiao XM, Domenech J, Lubroth J, Martin V, Slingenbergh J. Emerging Infectious Diseases 2006; 12: 1650.

7. Yasue M, Feare CJ, Bennun L, Fiedler W. Bioscience 2006; 56 : 923.

8. http://www.fao.org/docs/eims/upload//213826/AI_recommandationswildbirds.pdf. Accessed 15 June 2007.

9. Hobson KA. Oecologia 1999; 120: 314.

10. Webster MS, Marra PP, Haig SM, Bensch S, Holmes RT. Trends Ecol. Evol. 2002; 17: 76

11. Sung WHT. Science 2005; 310: 235.

12. http://www.fao.org/AG/againfo/subjects/documents/ ai/AVIbull032.pdf. Accessed 15 June 2007.

13. http://www.fao.org/AG/againfo/subjects/documents/ ai/AVIbull035.pdf. Accessed 15 June 2007.

14. Hobson KA, Bowen GJ, Wassenaar LI, Ferrand Y, Lormee H. Oecologia 2004; 141: 477.

15. Hobson KA, Wassenaar LI. Oecologia 1997; 109: 142.

16. http://isohis.iaea.org/userupdate/Waterloo/index.html. Accessed 15 June 2007.

17. Johnsgard PA. Cormorants, Darters, and Pelicans of the World, Smithsonian Institution Press: Washington and London, $1993 ; 227$

18. Mizutani H, Fukuda M, Kabaya Y, Wada E. Auk 1990; 107: 400.

19. Meehan TD, Rosenfield RN, Atudorei VN, Bielefeldt J, Rosenfield LJ, Stewart AC, Stout WE, Bozek MA. Condor 2003; 105: 567.

20. Wunder MB, Kester CL, Knopf FL, Rye RO. Oecologia 2005; 144: 607.

21. Knoff AJ, Macko SA, Erwin RM, Brown KM. Waterbirds 2002; 25: 142.

22. Craig H. Geochim. Cosmochim. Acta 1957; 12: 133.

23. Mariotti A. Nature 1983; 303: 685.

24. Lajtha K, Michener RH. Stable Isotopes in Ecology and Environmental Science. Blackwell Science: Oxford, 1994; xii.

25. Manly BFJ. Multivariate Statistical Methods: A Primer. Chapman and Hall: New York, 1986; 101.

26. Rocque DA, Ben-David M, Barry RP, Winker K. J. Ornithol. 2006; 147: 395.

27. Hobson KA, Atwell L, Wassenaar LI. Proc. Natl. Acad. Sci. USA 1999; 96: 8003.

28. Smith BN, Ziegler H. Botanica Acta 1990; 103: 335.

29. Johnsgard PA. Cormorants, Darters, and Pelicans of The World. Smithsonian Institution Press: Washington and London, 1993; 30.

30. Bearhop S, Thompson DR, Waldron S, Russell IC, Alexander G, Furness RW. J. Appl. Ecol. 1999; 36: 75.

31. Winkler R. Der Ornithologische Beobachter 1987; 84: 317.
32. Hobson KA, Brua RB, Hohman WL, Wassenaar LI. Auk 2000; 117: 129.

33. Neto JM, Newton J, Gosler AG, Perrins CM. J. Avian Biol. 2006; 37: 117.

34. Araguas-Araguas L, Froehlich K, Rozanski K. J. Geophys. Res. Atmospheres 1998; 103: 28721.

35. Hebert CE, Hobson KA, Shutt JL. Environ. Sci. Technol. 2000; 34: 1609.

36. Hoefs J. Stable Isotope Geochemistry (5th edn). Springer: Berlin, New York, 2004; 122.

37. Redfield AC, Friedman I. In Symposium on Marine Geochemistry. Rhode Island University Narragansett Marine Laboratory Occasional Publication, 1965; 149.

38. Owens NJP. Advances in Marine Biology 1987 24: 389.

39. Schell DM, Barnett BA, Vinette KA. Marine Ecol. Prog. Ser. 1998; 162: 11

40. Fry B. Limnol. Oceanogr. 1988; 33: 1182.

41. Hobson KA, Welch HE. Mar. Ecol. Prog. Ser. 1992; 84: 9.

42. Hatch KA, Crawford MA, Kunz AW, Thomsen SR, Eggett DL, Nelson ST, Roeder BL. Rapid Commun. Mass Spectrom. 2006; 20: 3367

43. Hobson KA, Alisauskas RT, Clark RG. Condor 1993; 95: 388.

44. Fry B, Sherr EB. Contrib. Mar. Sci. 1984 27: 13.

45. Rau GH, Mearns AJ, Young DR, Olsen RJ, Schafer HA, Kaplan IR. Ecology 1983; 64: 1314.

46. Peterson BJ, Fry B. Annu. Rev. Ecol. System. 1987; 18: 293.

47. Chisholm BS, Nelson DE, Schwartz HP. Science 1982; 216: 1131.

48. Craig H. Geochim. Cosmochim. Acta 1953; 3: 53.

49. Estep MLF, Vigg S. Can. J. Fish. Aquat. Sci. 1985; 42: 1712.

50. Fry B. Ecology 1991; 72: 2293.

51. Hesslein RH, Capel MJ, Fox DE, Hallard KA. Can. J. Fish. Aquat. Sci. 1991; 48: 2258.

52. Thompson DR, Furness RW. Auk 1995; 112: 493.

53. Hobson KA. Can. J. Zool. 1987; 65: 1210.

54. Hobson KA. Condor 1990; 92: 897.

55. Zhang TZ, Lian XM, Li LX, Cui QH, Li GY, Su JP. Zool. Res. 2003; 24: 235

56. Zhang TZ, Li LX, Lian XM, Cai ZY, Su JP. Waterbirds 2007; 30: 305.

57. http:/ / www.fao.org/docrep/field/003/U2896E/ U2896E00.htm\#ch1. Accessed 15 January, 2008.

58. Wood CM, Du JZ, Rogers J, Brauner CJ, Richards JG, Semple JW, Murray BW, Chen XQ, Wang YX. Physiol. Biochem. Zool. 2007; 80: 59.

59. Kline TC, Goering JJ, Mathisen OA, Poe PH, Parker PL. Can. J. Fish. Aquat. Sci. 1990; 47: 136.

60. Kline TC, Goering JJ, Mathisen OA, Poe PH, Parker PL, Scalan RS. Can. J. Fish. Aquat. Sci. 1993; 50: 2350.

61. Hobson KA, Welch HE. Can. J. Fish. Aquat. Sci. 1995; 52: 1195.

62. Rosenfeld JS, Roff JC. J. N. Am. Benthological Soc. 1992; 11: 1.

63. Aranyossy JF, Filly A, Tandia AA, Louvat D, Ousmane B, Joseph A, Fontes J-C. In Isotope Techniques in Water Resources Development. International Atomic Energy Agency: Vienna, 1991; 309.

64. http://bna.birds.cornell.edu.erl.lib.byu.edu/bna/species/ 553/articles/introduction Accessed 15 January, 2008.

65. Zhang FY, Young RL. The Study of Migratory Birds of China. China Forestry Publishing House: Beijing, 1997; 119.

66. Meehan TD, Giermakowski JT, Cryan PM. Isot. Environ. Health Stud. 2004; 40: 291.

67. Birchall J, O'Connell TC, Heaton THE, Hedges REM. J. Anim. Ecol. 2005; 74: 877.

68. Doucett RR, Marks JC, Blinn DW, Caron M, Hungate BA. Ecology 2007; 88: 1587.

69. Malej A, Faganeli J, Pezdic J. Mar. Biol. 1993; 116: 565.

70. Kelly JF, Ruegg KC, Smith TB. Ecological Applications 2005; 15: 1487.

71. http://isohis.iaea.org/userupdate/Waterloo/index.html. 